\title{
Digital technologies in support of students learning in Higher Education: literature review
}

\author{
Marta Pinto \\ mpinto@fpce.up.pt \\ Faculty of Psychology and Education Science of University of Porto, Portugal \\ Carlinda Leite \\ carlinda@fpce.up.pt \\ Faculty of Psychology and Education Science of University of Porto, Portugal
}

\begin{abstract}
Digital technologies are an integral part of Higher Education teaching, revealing a set of technologies chosen to integrate formal learning contexts, and therefore being used by students in support of learning. This paper presents a literature review mapping the digital technologies set for higher education students to use in formal education contexts, over the last five years between 2012 and 2017. Results show a pattern of technologies reflecting teacher's choice for methods combining face-to-face and at distance learning, frequently in relation to the adoption of flipped classroom methods. Mapping the digital technologies used by students, showed a pattern of three most used in a total of nine types identified. Institutional Learning Management Systems mainly support a wider access to information and learning materials, followed by technologies that promote publishing and sharing content related to class activities, and a broad range of technologies categorized under ICTs. The overall impact of use of technologies in students learning process and outcomes revealed to be positive, used with the intention to promote students' active engagement and participation in the learning process inside and outside the classroom walls. The data also revealed digital technologies to support more transmissive ways of teaching, facilitating students individually to Access, share and publish information, and significantly lesser used to promote collaborative and cooperative learning.
\end{abstract}

\section{Keywords}

Digital technologies; ICT; higher education; students; learning; literature review 


\section{Introduction}

Digital Technologies are an integral part of the debate on teaching and learning in Higher Education (Becker et al., 2017; Bullen \& Morgan, 2015). Institutions and people's life have been greatly influenced by technological developments, such as computers, portable devices and the internet, influencing their relation with information, knowledge and ways of working (Selwyn, 2016). Higher Education Institutions, at an organization and management level, offer technologybased computer infrastructures that support virtual organization and management of teaching and learning. Also, at a pedagogical and organizational level digital technologies have had an exponential use, generating expectations of an education transformation involving the physical space of schools and the ways to interact and deliver educational content (Pedro, Barbosa, \& Santos, 2018; G. Siemens \& P. Tittenberger, 2009). Expectations have been met half way. Effective transformations have occurred in learning processes and access to lectures and learning materials (Han \& Shin, 2016), more personalized learning (Vázquez-Cano, Meneses, \& SánchezSerrano, 2015), a change in the roles of teachers and learners, and the equitable access to higher education (Conole \& Alevizou, 2010; Henderson, Selwyn, \& Aston, 2017).

At the core focus of the transformations prompted by the integration of digital technologies in higher education teaching and learning are a wide and fast changing set of tools. Internet based digital technologies, such as Web 2.0 tools or social media tools have been game changers, mainly because they simultaneously support students in their everyday social lives and have the enhanced potential to support more shared process of learning, and support students' autonomy in learning (Armstrong \& Franklin, 2008; Conole \& Alevizou, 2010; Neira, Salinas, \& Crosetti, 2017; Norman, Din, Nordin, \& Ryberg, 2013; Sleeman, Lang, \& Lemon, 2016). The time dedicated to interaction between students and teachers is now flexible, continuing beyond classroom walls, in a process of engagement, content sharing, connection and communication. Devices such as mobile phones, tablets, e-book readers and mobile applications, have been considered prominent tools in higher education (Aresta, Pedro, \& Santos, 2015; Stevenson \& Hedberg, 2017), supporting and impacting interactions between teachers, students and peers (Becker et al., 2017). Hybrid learning environments merging face-to-face and blended learning and mobile learning have emerged. Environments combining the use of synchronous and asynchronous technologies (Garrison \& Kanuka, 2004), benefiting collaborative and connected learning (Aresta et al., 2015), discussions and knowledge sharing (Wesch, 2009). Learning spaces have also been redesigned, enabling physical lab experiments to be replaced by using virtual and augmented reality (Carbonell Carrera \& Bermejo Asensio, 2017; Dubovi, Levy, \& Dagan, 2017; Kingston et al., 2012), or simulationbased laboratories (Balakrishnan \& Woods, 2013; Estriégana-Valdehita, Plata, \& Medina-Merodio, 2017).

Pervasiveness of digital technologies in higher education have blurred the traditional borders between learning spaces and time, between formal and informal learning environments, between the use of specific tools for learning and personal use. Digital technologies and learning environments have transformed the "time for learning", now learning is "all the time".

The ongoing development of digital technologies and its use in higher educational settings creates expectations regarding how its' use will continue to transform, enhanced and support education (Selwyn, 2016). Therefore, it's important to look back and understand what technologies and how they have impacted students learning. Therefore, a literature review was performed in SCOPUS journals, on the past five years (2012 to 2017), for papers with empirical data concerning the use of digital technologies in support of higher education students learning, expecting to map emerging technologies and patterns of use. The question addressed in this review is: what digital technologies are supporting students learning in Higher Education? 


\section{Research overview}

This literature review follows previous research in this area namely developed by Marta Pinto (2012) focused on the digital technologies used in higher education institutions, now focusing on the analysis of studies empirical and other, conducted to identify digital technologies used by students in support of their learning in higher education.

The review, based in a search in SCOPUS database performed during January of 2018. This database was chosen because the intention was to obtain a review of the use of technologies by higher education students open to all areas of study, and SCOPUS is the largest abstract and citation database of peer-reviewed literature covering multiple fields of science, technology, medicine, social sciences, and arts and humanities.

In order to build the corpus of analysis, the first phase of the review narrowed the search to journal papers published between 2012 and 2017, published in English and Portuguese languages, combining the key-words 'higher education', 'technology', 'students' and 'learning' identified in the title, abstract or key-words. A total of 851 papers were identified at the end of this phase and imported to EndNote software. Secondly, was conducted a full review of the abstracts and when necessary a full review of the papers. To constitute the final corpus of analysis, criteria of inclusion and exclusion of the papers identified was applied. Papers were included when allowing the identification of one or more digital technologies used to support learning, and when the data collected was through a sample of higher education students. Papers were excluded when the technology identified was under development and being tested by students. A final set of 248 papers were identified and constituted the corpus of analysis at the end of the second phase. Thirdly, information was extracted from the papers and organized according to type of digital technology, student's degree level, year of publication, and learning methods adopted.

Regarding digital technologies, this paper adopts the definition by Selwyn et al (2016) "'Digital technology' can include but not limited to: computers, tablets, smart phones, FaceBook, Moodle, online library services, Google, YouTube, writing essays on Microsoft Word, etc. Digital technology also enables people to access the internet not just from home but in any location through portable devices." This is at the base of the review analysis, also sustained by the taxonomy for web environment Communication Technologies proposed by Batista, Morais and Ramos (2016) which integrates other taxonomies for social software's and media sharing (Conole \& Alevizou, 2010; Siemens \& P. Tittenberger, 2009). This taxonomy was chosen because it adds to the pre-existing ones, the category of digital institutional platforms such as LMS, a technology central to support the management of teaching and learning in higher education institutions. In the first moment of analysis, categorizing the papers according to the types of technologies. As result, three categories emerged and were added to the taxonomy, being: technologies for assessment and feedback; mobile technologies; and Information Communication Technologies (ICT). Therefore, the final taxonomy for digital technologies supporting learning in higher education includes the following 10 categories and examples of tools:

- Learning Management Systems (LMS): Blackboard, Moodle, WebCT, Platforms supporting online courses, etc.

- Publish and Share tools: Blogs, Wikis, Flickr, YouTube, Podcast, Social Bookmarking, eportfolio, Digital storytelling, e-books, Video lectures, etc.

- Collaborative systems: Google Docs, Social Bookmarking, Mind Maps, Wikis, Blogs, etc.

- Social networking: Facebook, Twitter, Hi5, LinkedIn, Ning, Academia.edu, etc.

- Interpersonal Communication tools: email, MSN, Skype, Forums, Video-conferencing, etc.

- Content Aggregation tools: RSS feeds, NetVibes, Google Reader, etc.

- 3D Virtual Worlds: Second Life, Habbo, Augmented reality, Games, Virtual labs, etc.

- Assessment and Feedback systems: Electronic marking, Clickers, Audio feedback, Computer note taking, etc. 
- Mobile tools: mobile applications internet based.

- Information and Communication Technologies (ICT): software or applications internet based (this category is used under two conditions: when the paper specifically refers to ICT, or when the paper does not specify a technology or set of technologies under study, or references specifically to information technology).

Within each category of digital technology, the tools are not mutually exclusive because they depend on how students and teachers use them to support learning. For example, a Wiki or a Blog can be used to publish and share contents, or to support collaborative work. The analysis of the information gathered was quantified by the number of papers published under each category, and the results integrate the quantitative and qualitative analysis.

\section{What digital technologies support higher education students learning?}

The digital technologies used to support higher education students learning, and focus of research are diverse (Figure 1), and ranging from the most used LMS to the least used mobile applications. The analysis revealed that from the total set of categories only one was missing, the content Aggregation tools (eg. RSS feeds, NetVibes, Google Reader, etc.) for which were not identified any papers. When analyzing the most and least used technologies by the total numbers of papers published, by students using them and year of publication, a set of three technologies as the most targeted in the publications as being used by students in support of their learning (Figure 1), being: LMS, ICT, and Publish and share technologies. Also, a pattern of the least used technologies, being: Mobile, Interpersonal communication, and collaborative.

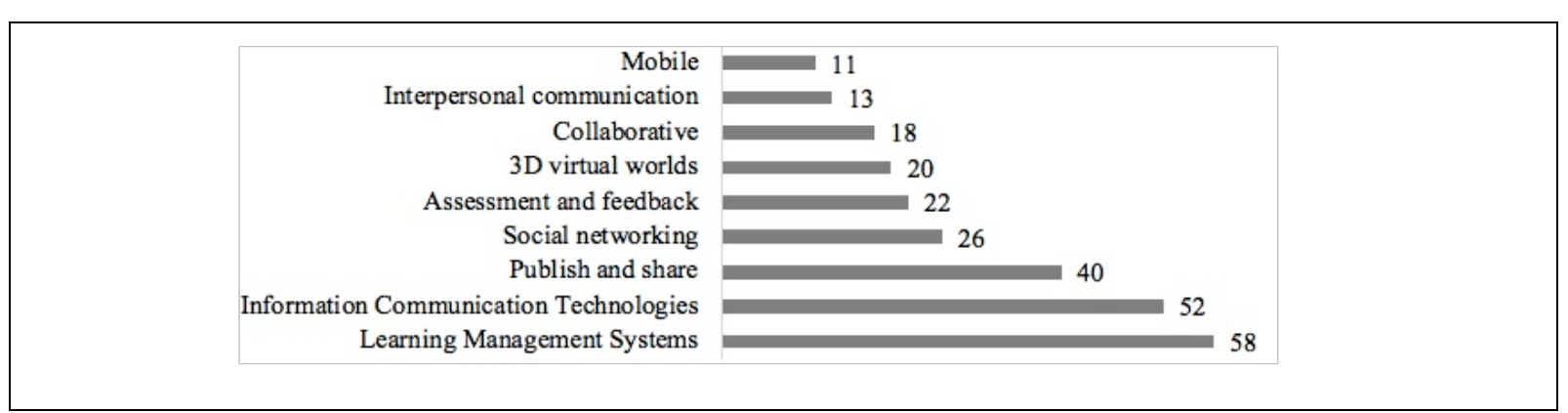

Figure. 1. Number of papers published per category of digital technology

In terms of the sample groups, the same pattern of digital technologies used by students to support their learning emerged. The majority of papers sample group were undergraduate students (132 papers), followed by post-graduates (50), international (3), students with disability (3) and non-traditional (1) (Figure 2).

Additionally, 83 papers were categorized under 'general' meaning the papers did not identify the students' degree or status.

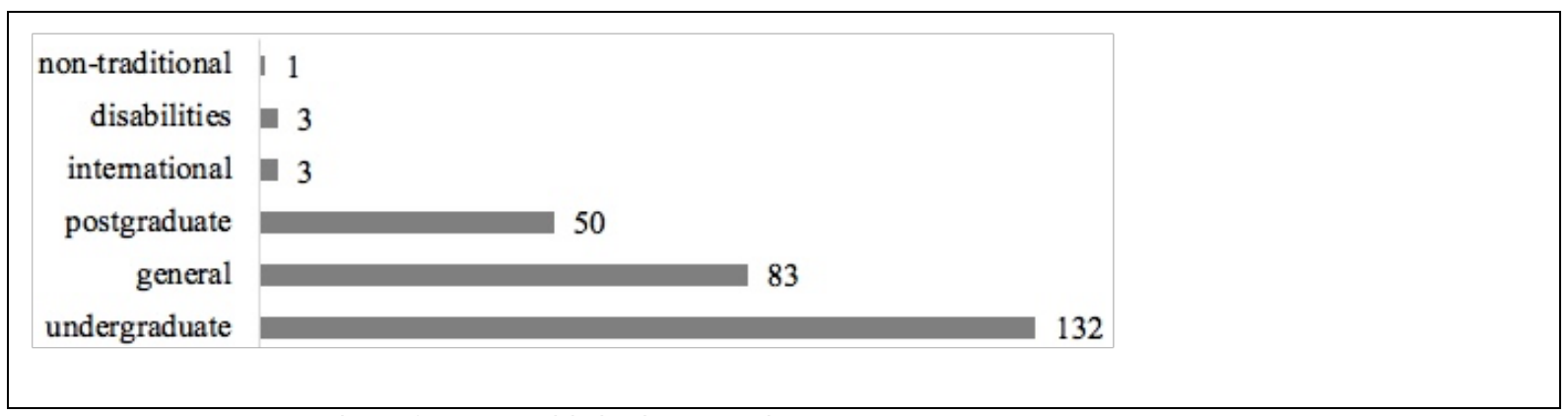

Figure. 2. Number of paper published per students status. 


\section{a. Learning Management Systems (LMS)}

The LMS platforms (58 papers) used by students in support of learning, regard to two main types of platforms. The first type are institutional platforms amongst the largest and most used for academic purposes, Moodle (8 papers) and Blackboard (4) (Pedró, 2009; Weller, 2007). These platforms provide access to resources and services in formal educational settings, supporting blended and e-learning practices (Dias, 2013; Dang, 2016). Other institutional offered LMS less used were supported specific study subjects (3) such as math, - e.g. ActivMathComp, Platform for Learning Calculus -, SPeCTRUM (1) and institutionally powered personal learning environment platform (1). The studies aimed to understand the impact on students learning outcomes of using of Moodle and Blackboard and showed there exists improvement in performance (Umek, Keržič, Aristovnik, \& Tomaževič, 2017), and also how it increases their motivation and engagement in learning processes (Samir Abou El-Seoud, Taj-Eddin, Seddiek, El-Khouly, \& Nosseir, 2014; Shurygin \& Krasnova, 2016). Results confirmed that its use has positive impact in students' academic outcomes and its use also supports communication with students, namely with international students (Wihlborg, Friberg, Rose, \& Eastham, 2017).

Research also approached the use of platforms offered by commercial organizations and that support online courses, identifying MOOCs (2), and other diverse types of online course platforms (4) ranging from Small Private Online Courses (SPOC) (García, Martin, de la Escalera, Armingol, \& Al-Kaff, 2016), virtual laboratories (M. A. Virtanen, Kääriäinen, Liikanen, \& Haavisto, 2017), and online courses with assistive technologies supporting students with learning disabilities (Heiman \& Shemesh, 2012). Although there is an emerging body of research related to the use of MOOCs in higher education (Pomerol, Epelboin, \& Thoury, 2015), in the total of papers only two papers addressed MOOCs indicating its possible response to a trend in online learning, and how learning styles affect students learning experience and influence their intentions to use this technology to support learning (Andone \& Vasiu, 2016; Chang, Hung, \& Lin, 2015). One paper focused on the use of Google Education (1) in support to flipped classroom model, promoting students selfregulated learning, continuous dialogue and collaborative interactions among peers (Blau \& Shamir-Inbal, 2017).

The studies focused on the use of Mobile LMS (2) also addressed in this review, focused on how it may influence students' academic achievement (Han \& Shin, 2016), in this case positively, and defining the factors that drive students' individual behavioral intention to adopt mobile learning such as task technology fit and attitude towards its use (Gan, Li, \& Liu, 2017).

LMS studies refer to its use mainly by undergraduates (30) and postgraduates (14), followed by fewer studies focusing on international students (2), and only one paper focused on its use by students with disabilities. The number of curricular areas of study in which these technologies were used was 14, from thesis development, to learning a foreign language, math, engineering, economy, psychology or science education.

\section{b. Information and Communication Technologies (ICT)}

The technologies that integrate this category, as explained previously, contemplate software or applications internet based and was adopted when the paper specifically referred to ICT, or when it did not specify one technology or set of technologies under study (e.g. when surveying on the use of diverse types of technologies, or technologies in general). There were 52 papers categorized under ICT, with studies mainly focused on the use of ICT to support students learning in an academic and social perspectives (29) (Edmunds, Thorpe, \& Conole, 2012; Gallardo Echenique, Marqués Molías, \& Bullen, 2015). Studies looked at how digitally mastered students are using ICT and if there are differences of use identified between different age groups, showing there are no significant difference (Lai \& Hong, 2015; Romero, Guitert, Sangrà, \& Bullen, 2013). Studies did show the impact of using ICT both in face to face and blended learning (Olelewe \& Agomuo, 2016) (7), at the levels of better academic performance which reflected on higher scores (Lemus-Zúñiga 
et al., 2015; Mancillas \& Brusoe, 2016; Muñoz-Repiso \& Tejedor, 2012; Valentín et al., 2013). Students perceptions of regarding the use of ICT on their academic work are positive (Russo, Zhang, \& Fallon, 2015), which reflects on the time dedicated to using them to support their academic learning, being approximately half of their time of study (Faizi, Chiheb, \& El Afia, 2015), the development of e-skills (Yousseff, 2013). Regarding students with disabilities, the positive aspect of ICT use relates to their social development, although the digital capital depends on the access to technologies and its accessibility (Seale, 2013; Seale, Georgeson, Mamas, \& Swain, 2015).

However, students also perceive disadvantages in technology mediated interactions, mainly focusing on increasing stress, conflict, misunderstandings in relations (Russo et al., 2015), or incivility between student-to-student and student-to-faculty communication (Bartlett \& Bartlett, 2016). Also, in more collaborative and flexible pedagogical approaches that require of students a more flexible approaches to learning, online participation and communication may be considered difficult (Costa, 2017).

The papers categorized under ICT refer mostly to its use to support learning of undergraduates (23), postgraduates (13). The number of curricular areas of study in which these technologies were used as 11, within which: Basic programing language, Educational Psychology, Health, Language, Governance and others.

\section{c. Publish and share}

In the category of Publish and share technologies (40), video technologies (13) were the technology most studied as used by students in face-to-face or at a distance learning, often in relation to flipped classroom methods. Videos of classroom lectures or field experiences, using lecture capture video technologies, were used as a complement to support students learning process outside of class and preparation for assessment, allowing them to revise class content at their own pace, (Cooke et al., 2012; Fuller \& France, 2016). Results show that the use of video technologies reflected on students more positive engagement and participation in class (Blair, Maharaj, \& Primus, 2016; Estriégana-Valdehita et al., 2017; Ferrer-Torregrosa et al., 2016; Mattis, 2015). Ambitioning to support more reflective learning, tools of video annotation were used, showing that a graded use of the tool impacts students engaged learning behavior, although it is not sufficient to sustain it in subsequent courses (Mirriahi, Liaqat, Dawson, \& Gašević, 2016). The use of video tools to produce digital storytelling was also studied, as a support for reflective and critical engagement in learning, although raising ethical questions related to content that may result from students' personal experiences being published online and publicly consumed (Stewart \& Ivala, 2017).

Other publish and share tools, such as Podcasts (7) were used with the same aim as video technologies, for more transmissive practices such as registering class moments, and facilitate students access to it settings outside of class (Gachago, Livingston, \& Ivala, 2016). Students tended to perceive podcasts as a useful tool to support learning, and being easy to use, predicting their acceptance to use this tool for learning (Jiménez-Castillo, Sánchez-Fernández, \& MarínCarrillo, 2017; Merhi, 2015; Tolulope, Adenubi, \& Oluwole, 2015; Zacharis, 2012).

Regarding blogs (7) the studies revealed its use mainly for activities involving writing, sharing written content with peers and teachers, and also for peer-reviews of students work (Bridges, Chang, Chu, \& Gardner, 2014; Dalgarno, Reupert, \& Bishop, 2015). Blogs were considered, by students, as a useful tool to support learning, involving written discussion of course materials, sharing content related to a course allowing to follow how students engage with content, and for personal reflections (Badenhorst \& Mather, 2014; Chawinga, 2017). Students level of experience using this tool may influence its perceived value as tools to support learning (S. Bennett, Bishop, Dalgarno, Kennedy, \& Waycott, 2012). 
The studies focused on the use of e-books (3) in higher education, identified that students perceived ease of use, satisfaction and usefulness were factors that contribute to its use, identifying its access at any time and from anywhere as the main advantage for using e-books (Maduku, 2015; Sieche, Krey, \& Bastiaens, 2013; Tri-Agif, Noorhidawati, \& Ghalebandi, 2016).

Regarding the use of e-portfolios (3) by higher education students, two of the studies focused on its use in relationship to the career, looking to support career development learning in the case of postgraduates (Yang, Coleman, Das, \& Hawkins, 2015), and support learning process that prompt students' adoption of future-oriented thinking in relation to future lives and careers (D. Bennett, Rowley, Dunbar-Hall, Hitchcock, \& Blom, 2016).

Other tools, such as Wiki (1), were identified as being used for individual writing tasks and leading to improved outcomes in writing (Allen, 2012). QRcodes (1) were used to support field-based learning, benefiting students access to online resources outside of class although dependent on stable wifi connection (Chapple, Weir, \& Martin, 2017).

The number of studies focused on the use of publishing and sharing technologies, regarding its use by undergraduate students (23), are higher in comparison to the use of the same tools by postgraduates (5) and non-traditional students (1). The areas of study in which these technologies were used were 18 in total, featuring: Music, Social Sciences, Cancer study, Biology, Nursing, Engineering, Geography, Math, Language and other.

\section{d. Social Networks}

Within the social networking technologies (26 papers), Facebook was the most studied in relation to its use to support students learning (12), namely its features such as Facebook groups and Facebook pages. This social network facilitates communication and interaction between students and advisors (Amador \& Amador, 2014) and between peers (Cheng, Chan, Kong, \& Leung, 2016; Dickie \& Meier, 2015; Magogwe, Ntereke, \& Phetlhe, 2015; Sayımer, Yüksel, \& Demir, 2015). This tool also supported students-centered learning and engaged students in and beyond classroom, with learning materials and development of group assignments (Cheng et al., 2016; Deepak, Wisner, \& Benton, 2016; Magogwe et al., 2015).

The use of other social media technology such as Twitter (4), was also studied as a support for class interactions between teachers and students (Aslam, 2017; Solmaz, 2016), providing spaces to establish and maintain a participatory community of inquiry (Solmaz, 2016), and to share and discuss course materials and reflections (Chawinga, 2017).

The use of social media proved to encourage informal learning both in and out of classes (Migin \& Falahat, 2016), and that its use is perceived by students as a positive contributor to academic learning experiences (Sheriff, 2012; Sobaih \& Moustafa, 2016). Nevertheless, studies revealed that it is important for students to have positive experiences of collaborative learning using social media, in order to become more likely that its' use will contribute to the improvement of students learning performance and social media capabilities (Jang, 2015; Marstio \& Kivelä, 2014). Josefsson (2016) described that students have different perceptions of the distinct use of social media, dividing it between educational, private and career-building. The distinct uses of social media also emerged in Wycotts (2017) study, revealing that although students experienced benefits of its use for educational purposes, such as when sharing course related work and being part of a learning community, they also showed negative engagements revealing feelings of conflict about the private and public use. Additionally, students showed difficulty in the process of transferring social media skills gained in a private use of these tools, to an educational and professional use that required them to build distinct identities, showing also resistance in learning how to participate in social media with distinct identities (Novakovich, Miah, \& Shaw, 2017).

In the papers analysed, social media tools are most used to support learning of undergraduates 
(18), followed by postgraduate (4) and international students (1). There were 11 areas of study in which these technologies were used, involving Turism, Social work, Engineering, Business, Politics, International relations, Management Information Systems and other.

\section{e. Assessment and feedback}

Concerning assessment and feedback technologies (22), the tools used are diverse, compiling a set of nine tools listed in the papers analysed. Response technologies (5) were the most used and with different approaches, as example, clickers and a quiz maker tool (Riddle) were used by students in class, requiring them to interact with class content and obtaining an immediate feedback to the interaction. These technologies can also be used to enable anonymity in peer assessment in combination with written and oral feedback in face-to-face settings (Raes, Vanderhoven, \& Schellens, 2015). Results showed that using such tools contributed to enhance students active learning, increasing their participation and engagement in class (Hedén \& Ahlstrom, 2016; Singh \& Wassermann, 2016; Terrion \& Aceti, 2012). When anonymity in peer assessment was enabled, student's manifest positive attitudes and feelings of comfort towards feedback (Raes, Vanderhoven, \& Schellens, 2015). Students also valued e-assessment opportunities due to its timelier feedback (Singh \& Wassermann, 2016).

Feedback was also shown to be provided through video (4) and audio (4) synchronous and asynchronous software, providing lecture summaries to students and supporting one-to-one communication between students and teachers as well as with the whole class work (Issa, Issa, \& Chang, 2012; Jones, Georghiades, \& Gunson, 2012; Mathisen, 2012). The advantages of asynchronous communication and feedback to students' work was evident in all the studies, stating to increase students' interest and motivation, encouraging them to engage with teacher's feedback as well as improving the quality of engagement in learning (Crook et al., 2012; Issa et al., 2012; Jones et al., 2012; Mathisen, 2012). Students perceive audio feedback to be better than video or written feedback, arguing it is returned more promptly (Crook et al., 2012; Parkes \& Fletcher, 2017). The use of electronic marking tools can also result in more timely feedback for students, without impacting on quality of the assessment (Sopina \& McNeill, 2015).

Overall, students are shown to have high positive perceptions of online assessment (Attia, 2014; Lee, 2015), and the higher satisfaction felt may promote students more active participation in learning (Blanc, Benlloch-Dualde, \& Benet, 2015), and learning effectiveness (Lu \& Jeng, 2012). The structure of a formative feedback also impacts the way students perceive it, adding to the timely return, a supportive and encouraging feedback, guiding students on how they may improve work (Hennessy, 2014).

The papers analysed focused mostly on the use of these feedback and assessment technologies by undergraduates (12), followed by a lower number of studies with postgraduates (5) and international students (1). In seven papers were identified the specific areas of study within which these technologies were integrated: Business, Chemistry, Computer Science, Computer Information Systems, Language, Human Geography and Nursing.

\section{f. 3D virtual worlds}

$3 \mathrm{D}$ virtual world technologies (20 papers) in a set of six types of technologies, are being used by higher education students in learning.

In the case of remote virtual labs (2) were identified to types of use supporting students learning allowing a remote access (Kara, Cagiltay, \& Dalveren, 2014), or supporting face-to-face learning allowing students to access the virtual lab in class (Marques et al., 2014). Both remote of face-toface access to the remote virtual labs showed a positive effect on students' engagement levels in learning with significant improvement in the learning process, adding feelings of satisfaction 
towards the course where this technology is integrated (Kara et al., 2014; Marques et al., 2014).

On the other hand, there are simulator technologies, such as Virtual and augmented reality environments and others, that support students acquisition of essential skills by interacting and living simulated field experiences or real-life settings, simultaneously learning by doing and assessing their progress through feedback from the system (Balakrishnan \& Woods, 2013; Dubovi et al., 2017; Carbonell Carrera \& Bermejo Asensio, 2017; Ferrer-Torregrosa et al., 2016; Kingston et al., 2012). Example of simulation activities relate to health training in treating patients, having the student interact in the environment in the form of an avatar for example (Lambert \& Watkins, 2013), and related to other professional practices (Mathews, Andrews, \& Luck, 2012; Srifa, 2016).

These virtual and simulation learning experiences complement face-to-face teaching, emerging within blended learning contexts specifically when adopting flipped classroom methods (FerrerTorregrosa et al., 2016), and mobile earning are chosen by teachers (Kingston et al., 2012).

Games as a technology used by higher education students for learning ( 2 papers) emerged as associated to either a more playful approach to learning, or a competitive approach. Activities such as language learning through games showed positive impacts on students' development of communication and language skills, as well as on motivation and cooperation between students and between teachers and students (Baranova \& Ladner, 2016). Activities focused on skills reinforcement used drill-quiz type games (González-Tablas, De Fuentes, Hernández-Ardieta, \& Ramos, 2013). These learning experiences through games were well received by students who consider games as a motivating learning practice, benefiting from the different degrees of player and non-player goals incorporated in the games (Araujo, Spritzer, \& de Souza, 2012; Baranova \& Ladner, 2016).

These tools were studied in their use to support students at an undergraduate (9) and postgraduate (4) level. The areas of study in which these technologies were used were 13 in total, featuring: Engineering, Geography, Mathematics, Anatomy, Language, Topography, Pharmacology, Information Systems, Digital Communication, Mental health, Electronics, Technology and Marketing.

\section{g. Collaborative}

Studies on the use of collaborative technologies (18) covered tools such as wikis and shared documents, and as expected most used to support collaborative learning.

Wikis (9) were the most used of these tools namely supporting students blended learning experience (Menkhoff \& Bengtsson, 2012).and development of writing skills (Stafford, 2014), building collaborative knowledge (Buraphadeja \& Kumar, 2012), and collaborative abilities that may be required in future professional settings (Zitzelsberger, Campbell, Service, \& Sanchez, 2015). Overall, students felt motivation using wikis to support learning, although studies identified as barriers to its effective use the lack of dominance of the tool and the lack of understanding the value of the tool for collaborative learning (Costa, Alvelos, \& Teixeira, 2013).

In concern to the use of shared documents (4), such as Google Drive documents and Etherpad, also used to promote collaborative work between students, sharing, editing, writing, they were also used to comment each other's work, supporting new approaches to communication where students were required to learn rules for commenting and editing each other's work (Brodahl, 2014; Erturk, 2016).

Students perceive collaborative tools such as wikis, shared documents or blogs, to be useful, affecting their levels of motivation and cognitive learning (Fessakis, Dimitracopoulou, \& Palaiodimos, 2013; Garcia-Vera \& Chiner, 2017; Waldeck \& Dougherty, 2012).

These tools were most studied in the support of undergraduate (10) and postgraduate (4) students learning. The areas of study that integrate these technologies were a total of six, 
featuring: teacher education, Entrepreneurship, Engineering, Hypermedia supported Education, Language and Nursing.

\section{h. Interpersonal Communication}

Interpersonal Communication technologies were studied in 13 papers, and covered both synchronous and asynchronous tools. Videoconferencing tools (3) and online forums (3) were used by students to communicate and collaborate with other students (Arias-Masa, Alonso-Díaz, CuboDelgado, Gutiérrez-Esteban, \& Yuste-Tosina, 2014; Blau \& Shamir-Inbal, 2017), to communicate with teachers in moments outside the class (Borup, West, \& Graham, 2012; Alzahrani, 2017; Cook-Sather, 2017) in a continuous dialogue and interaction, stimulating students participation in class (Arias-Masa et al., 2014; Blau \& Shamir-Inbal, 2017). This continuous dialogue was perceived by students as useful. Online forums were used to encourage the embrace of a partnership approach to teaching and learning, an amplification of student's voice, in promotion of active learning and development of reflective learning practices (Alzahrani, 2017; Bharuthram \& Kies, 2013; Cook-Sather, 2017).

Other tools, such as MSN Messenger and WhatsApp (So, 2016) or Twitter (P. Virtanen, Myllärniemi, \& Wallander, 2013), were used with the aim to facilitate interactions and communication in class moments.

These technologies were most used to support learning of undergraduates (6) and postgraduates (3). The areas of study that explored the use of these types of technologies were: Teacher education and training, Social work and Language.

\section{i. Mobile}

The use of mobile technologies by students was covered in 11 papers, none of which referred to specific sets of tools. Its use integrated mobile learning settings (Aldhafeeri \& Male, 2016; Yi, You, \& Bae, 2016) combining both face-to-face and at a distance learning (Jabbour, 2014; Klimova \& Poulova, 2016). Students perceive its use has a positive effect in their learning process in class and when using them outside to complement class activities and strengthen academic tasks, in example, to search using the online library (Jabbour, 2014; Klimova \& Poulova, 2016; SánchezLugo \& Domínguez-Flores, 2013; Viberg \& Grönlund, 2013). However, students are aware that an effective use may impact their performance depending on their domain of information literacy (Carmen-Ricoy \& Da Silva-Couto, 2016), and the technology fit tasks (Yi et al., 2016).

These technologies were most used by undergraduate (4) and post graduate (1) students. The information about the areas of study that explored the use of mobile technologies were two: language and social education.

\section{Conclusion}

This literature review emphasizes and supports previous research stressing that digital technologies are transversely and widely used by students in higher education, to support of their academic learning processes. This use happens within class settings, with teachers frequently adopting a combination of face-to-face and at distance teaching and learning methods. However, this review evidences a set of technologies with a stronger research focus, reflecting greater number of papers published over the five-year span between 2012 and 2017, protraying a pattern of three technology types, mixing institutionaly offered technologies and other: LMS, ICTs, and Publish and share technologies. 
The use of LMS technologies integrate institutionaly supported platforms (e.g. Moodle and Blackboard) and commercial oplatforms (e.g. Google Education). The institutional platforms were most used by students, reflecting a high investment of institutions in these learning management platforms, mainly used promote students access to course materials and online activities proposed by the teacher. Yet, although collaborative were not reported, it was recognized the potential of these platforms to support collaborative activities.

The use of ICTs, here understood as all internet-based technologies, showed that when used to support academic learning were related to pedagogical approaches centered to support collaborative, cooperative and autonomous learning. When so, it positively affected students' academic performance and learning outcomes, and promoted the development of digital skills. However, these appraches with stronger emphasis on online participation, communication and collaboration revealed students difficulties in adopting the new roles required, the same that usually are not required of them in academic contexts. The same difficulty emerged when students were required to use of social media tolos within students-centered learning, showing feelings of conflict towards willingness to learn how build distinct social media identities for private purposes versus educational and career-building purposes.

As shown in this review, the number of papers focusing on collaborative approaches is reduced when compared to more transmissive ways of teaching and learning. This is reinforced by the evidence that the use of collaborative technologies is one of the three types of technology less used by students in this review, and therefore less proposed by teachers to integrate the teaching and learning proceses. While technologies that support publishing content, supporting and widening access to course materials are on the upper three types of technologies most used to support students learning.

Despite the different technologies and uses, they are mostly adopted in settings that combine face-to-face and at a distance learning, frequently in relation to flipped classroom methods, creating flexible learning spaces and of access to the learning spaces. Studies frequently referred to benefits in promoting students' active engagement and participation in the learning process, inside and outside the classroom walls and timeframe. Overall, the use of all the categories of digital technologies reported more frequently to have a positive impact in students learning process and outcomes.

Mapping the digital technologies used over the last five years allows us to look forward and further reflect about about the need for educators, and in our view also researchers within which we include ourselves, to go beyond the question of what is being used, into the question of 'what matters' as Selwyn (2016) has also presented, therefore looking to contribute to the further research and discussion concerning the use of digital technologies in learning in higher education.

\section{References}

Aldhafeeri, F., \& Male, T. (2016). Investigating the learning challenges presented by digital technologies to the College of Education in Kuwait University. Education and Information Technologies, 21(6), 1509-1519. doi:10.1007/s10639-015-9396-2

Alzahrani, M. G. (2017). The effect of using online discussion forums on students' learning. Turkish Online Journal of Educational Technology, 16(1), 164-176.

Amador, P., \& Amador, J. (2014). Academic advising via Facebook: Examining student help seeking. Internet and Higher Education, 21, 9-16. doi:10.1016/j.iheduc.2013.10.003

Andone, D., \& Vasiu, R. (2016) MOOCs in higher education-flipped classroom or a new smart learning model? In. Lecture Notes in Educational Technology (pp. 303-307). 
Araujo, C. M., Spritzer, I. M. P. A., \& de Souza, C. G. (2012). Technology innovation - Electronic game in the Brazilian higher education. Journal of Technology Management and Innovation, 7(3), 32-43.

Aresta, M., Pedro, L., \& Santos, C. (2015). Mobile learning and higher education: A theoretical overview. Journal of Mobile Multimedia, 11(1-2), 147-156.

Arias-Masa, J., Alonso-Díaz, L., Cubo-Delgado, S., Gutiérrez-Esteban, P., \& Yuste-Tosina, R. (2014). Assessment of the use of synchronous virtual classrooms in higher education. New Educational Review, 38(4), 223-237.

Armstrong \& Franklin, T., J. (2008). A review of current and developing international practice in the use of social networking (Web 2.0) in higher education. In: Franklin Consulting.

Aslam, W. (2017). Videoconferencing and higher education teaching in Politics and International Relations classrooms. Politics, 37(4), 500-519. doi:10.1177/0263395716633708

Attia, M. A. (2014) Postgraduate students' perceptions toward online assessment: The case of the faculty of education, Umm Al-Qura university. In: Vol. 24. International Perspectives on Education and Society (pp. 151-173).

Badenhorst, C., \& Mather, C. (2014). Blogging geographies. Journal of Geography in Higher Education, 38(2), 193-207. doi:10.1080/03098265.2014.908276

Balakrishnan, B., \& Woods, P. C. (2013). A comparative study on real lab and simulation lab in communication engineering from students' perspectives. European Journal of Engineering Education, 38(2), 159-171. doi:10.1080/03043797.2012.755499

Baranova, A. R., \& Ladner, R. A. (2016). Role of a game as a mechanism for maintenance of students' educational motives when learning a foreign language. Social Sciences (Pakistan), 11(14), 36233626.

Barrett, M. E., Swan, A. B., Mamikonian, A., Ghajoyan, I., Kramarova, O., \& Youmans, R. J. (2014). Technology in note taking and assessment: The effects of congruence on student performance. International Journal of Instruction, 7(1), 49-58.

Bartlett, M. E., \& Bartlett, J. E. (2016). Case study on the impact of technology on incivility in higher education. Journal of Educators Online, 13(2), 1-18.

Batista, J., Morais, S., \& Ramos, F. (2016). Researching the Use of Communication Technologies in Higher Education Institutions in Portugal. In M. Pinheiro \& D. Simões (Eds.), Handbook of Research on Engaging Digital Natives in Higher Education Settings (pp. 280 - 303). Hershey, PA, USA: IGI Global.

Becker, S. A., Cummins, M., Davis, A., Freeman, A., Glesinger Hall, C., \& Ananthanarayanan, V. (2017). NMC Horizon Report: 2017 Higher Education Edition. Retrieved from Austin, Texas:

Ben Youssef, A., Dahmani, M., \& Omrani, N. (2013). Information technologies, students' e-skills and diversity of learning process. Education and Information Technologies, 20(1), 141-159. doi:10.1007/s10639013-9272-x

Bennett, D., Rowley, J., Dunbar-Hall, P., Hitchcock, M., \& Blom, D. (2016). Electronic portfolios and learner identity: An eportfolio case study in music and writing. Journal of Further and Higher Education, 40(1), 107-124. doi:10.1080/0309877X.2014.895306

Bennett, S., Bishop, A., Dalgarno, B., Kennedy, G., \& Waycott, J. (2012). Implementing web 2.0 technologies in higher education: A collective case study. Computers \& Education(0). doi:10.1016/j.compedu.2011.12.022

Bharuthram, S., \& Kies, C. (2013). Introducing e-learning in a South African higher education institution: Challenges arising from an intervention and possible responses. British Journal of Educational Technology, 44(3), 410-420. doi:10.1111/j.1467-8535.2012.01307.x

Blair, E., Maharaj, C., \& Primus, S. (2016). Performance and perception in the flipped classroom. Education and Information Technologies, 21(6), 1465-1482. doi:10.1007/s10639-015-9393-5

Blanc, S., Benlloch-Dualde, J. V., \& Benet, G. (2015). Engaging students in an undergraduate computer technology course: An active-learning approach. International Journal of Engineering Education, $31(2), 610-618$.

Blau, I., \& Shamir-Inbal, T. (2017). Re-designed flipped learning model in an academic course: The role of cocreation and co-regulation. Computers and Education, 115, 69-81. doi:10.1016/j.compedu.2017.07.014 
Borup, J., West, R. E., \& Graham, C. R. (2012). Improving online social presence through asynchronous video. Internet and Higher Education, 15(3), 195-203. doi:10.1016/j.iheduc.2011.11.001

Bridges, S., Chang, J. W. W., Chu, C. H., \& Gardner, K. (2014). Blended learning in situated contexts: 3-year evaluation of an online peer review project. European Journal of Dental Education, 18(3), 170-179. doi:10.1111/eje.12082

Bullen, M., \& Morgan, T. (2015). Digital learners in higher education: Implications for teaching, learning \& technology. Teaching and learning in digital worlds: Strategies and issues in higher education, 11-19.

Buraphadeja, V., \& Kumar, S. (2012). Content analysis of wiki discussions for knowledge construction: Opportunities and challenges. International Journal of Web-Based Learning and Teaching Technologies, 7(2), 28-42. doi:10.4018/jwltt.2012040103

Carbonell Carrera, C., \& Bermejo Asensio, L. A. (2017). Landscape interpretation with augmented reality and maps to improve spatial orientation skill. Journal of Geography in Higher Education, 41(1), 119-133. doi: $10.1080 / 03098265.2016 .1260530$

Carmen-Ricoy, M., \& Da Silva-Couto, M. J. V. (2016). Digital mobile devices and skills to use in the "knowledge society. Convergencia, 23(70), 59-85.

Chang, R. I., Hung, Y. H., \& Lin, C. F. (2015). Survey of learning experiences and influence of learning style preferences on user intentions regarding MOOCs. British Journal of Educational Technology, 46(3), 528-541. doi: 10.1111 bjet. 12275

Chapple, D., Weir, B., \& Martin, R. S. (2017). Can the incorporation of quick response codes and smartphones improve field-based science education? International Journal of Innovation in Science and Mathematics Education, 25(2), 49-71.

Chawinga, W. D. (2017). Taking social media to a university classroom: teaching and learning using Twitter and blogs. International Journal of Educational Technology in Higher Education, 14(1). doi: $10.1186 /$ s41239-017-0041-6

Cheng, I. N. Y., Chan, J. K. Y., Kong, S. S. Y., \& Leung, K. M. Y. (2016). Effectiveness and obstacle of using Facebook as a tool to facilitate student-centred learning in higher education. Asia-Pacific Forum on Science Learning and Teaching, 17(2).

Conole, G., \& Alevizou, P. (2010). A literature review of the use of Web 2.0 tools in Higher Education. Walton Hall, Milton Keynes, UK: The Open University, retrieved February, 17, 2011.

Cook-Sather, A. (2017). Virtual forms, actual effects: how amplifying student voice through digital media promotes reflective practice and positions students as pedagogical partners to prospective high school and practicing college teachers. British Journal of Educational Technology, 48(5), 1143-1152. doi: $10.1111 /$ bjet. 12523

Cooke, M., Watson, B., Blacklock, E., Mansah, M., Howard, M., Johnston, A., . . Murfield, J. (2012). Lecture capture: First year student nurses' experiences of a web-based lecture technology. Australian Journal of Advanced Nursing, 29(3), 14-21.

Costa, C., Alvelos, H., \& Teixeira, L. (2013). The students' motivation to use the wiki technology: A practical study in higher education. Educacao e Pesquisa, 39(3), 775-790. doi:10.1590/S1517_97022013000300014

Costa, C., \& Harris, L. (2017). Reconsidering the technologies of intellectual inquiry in curriculum design. Curriculum Journal, 28(4), 559-577. doi:10.1080/09585176.2017.1308260

Crook, A., Mauchline, A., Maw, S., Lawson, C., Drinkwater, R., Lundqvist, K., . . . Park, J. (2012). The use of video technology for providing feedback to students: Can it enhance the feedback experience for staff and students? Computers and Education, 58(1), 386-396. doi:10.1016/j.compedu.2011.08.025

Dalgarno, B., Reupert, A., \& Bishop, A. (2015). Blogging while on professional placement: explaining the diversity in student attitudes and engagement. Technology, Pedagogy and Education, 24(2), 189-209. doi:10.1080/1475939X.2013.847481

Deepak, A. C., Wisner, B. L., \& Benton, A. D. (2016). Intersections between Technology, Engaged Learning, and Social Capital in Social Work Education. Social Work Education, 35(3), 310-322. doi: $10.1080 / 02615479.2016 .1154661$

Dickie, V. A., \& Meier, H. (2015). The facebook tutor: Networking education. Ubiquitous Learning, 8(2), 1-12. 
Dubovi, I., Levy, S. T., \& Dagan, E. (2017). Now I know how! The learning process of medication administration among nursing students with non-immersive desktop virtual reality simulation. Computers and Education, 113, 16-27. doi:10.1016/j.compedu.2017.05.009

Edmunds, R., Thorpe, M., \& Conole, G. (2012). Student attitudes towards and use of ICT in course study, work and social activity: A technology acceptance model approach. British Journal of Educational Technology, 43(1), 71-84. doi:10.1111/j.1467-8535.2010.01142.x

Estriégana-Valdehita, R., Plata, R. B., \& Medina-Merodio, J. A. (2017). Educational technology in flipped course design. International Journal of Engineering Education, 33(4), 1199-1212.

Faizi, R., Chiheb, R., \& El Afia, A. (2015). Students' perceptions towards using Web 2.0 technologies in education. International Journal of Emerging Technologies in Learning, 10(6), 32-36. doi:10.3991/ijet.v10i6.4858

Ferrer-Torregrosa, J., Jiménez-Rodríguez, M. Á., Torralba-Estelles, J., Garzón-Farinós, F., Pérez-Bermejo, M., \& Fernández-Ehrling, N. (2016). Distance learning ects and flipped classroom in the anatomy learning: Comparative study of the use of augmented reality, video and notes. BMC Medical Education, 16(1). doi:10.1186/s12909-016-0757-3

Fessakis, G., Dimitracopoulou, A., \& Palaiodimos, A. (2013). Graphical interaction analysis impact on groups collaborating through blogs. Educational Technology and Society, 16(1), 243-253.

Fuller, I. C., \& France, D. (2016). Does digital video enhance student learning in field-based experiments and develop graduate attributes beyond the classroom? Journal of Geography in Higher Education, 40(2), 193-206. doi:10.1080/03098265.2016.1141186

Gachago, D., Livingston, C., \& Ivala, E. (2016). Podcasts: A technology for all? British Journal of Educational Technology, 47(5), 859-872. doi:10.1111/bjet.12483

Gallardo Echenique, E., Marqués Molías, L., \& Bullen, M. (2015). Students in higher education: Social and academic uses of digital technology. RUSC Universities and Knowledge Society Journal, 12(1), 25-37. doi:10.7238/rusc.v12i1.2078

Gan, C., Li, H., \& Liu, Y. (2017). Understanding mobile learning adoption in higher education An empirical investigation in the context of the mobile library. Electronic Library, 35(5), 846-860. doi:10.1108/EL04-2016-0093

García, F., Martin, D., de la Escalera, A., Armingol, J. M., \& Al-Kaff, A. H. (2016). Enhancing engineering learning through SPOC courses. International Journal of Technologies in Learning, 23(3), 15-20.

Garcia-Vera, V. E., \& Chiner, E. (2017). Factors influencing graduate students' preference of software tools for building engineering applications. International Journal of Engineering Education, 33(1), 128-137.

Garrison, D. R., \& Kanuka, H. (2004). Blended learning: Uncovering its transformative potential in higher education. The Internet and Higher Education, 7(2), 95-105. doi:10.1016/j.iheduc.2004.02.001

González-Tablas, A. I., De Fuentes, J. M., Hernández-Ardieta, J. L., \& Ramos, B. (2013). Leveraging quiz-based multiple-prize web tournaments for reinforcing routine mathematical skills. Educational Technology and Society, 16(3), 28-43.

Han, I., \& Shin, W. S. (2016). The use of a mobile learning management system and academic achievement of online students. Computers and Education, 102, 79-89. doi:10.1016/j.compedu.2016.07.003

Hedén, L., \& Ahlstrom, L. (2016). Individual response technology to promote active learning within the caring sciences: An experimental research study. Nurse Education Today, 36, 202-206. doi:10.1016/j.nedt.2015.10.010

Heiman, T., \& Shemesh, D. O. (2012). Students With LD in Higher Education: Use and Contribution of Assistive Technology and Website Courses and Their Correlation to Students' Hope and Well-Being. Journal of Learning Disabilities, 45(4), 308-318. doi:10.1177/0022219410392047

Henderson, M., Selwyn, N., \& Aston, R. (2017). What works and why? Student perceptions of 'useful' digital technology in university teaching and learning. Studies in Higher Education, 42(8), 1567-1579. doi:10.1080/03075079.2015.1007946

Hennessy, C., \& Forrester, G. (2014). Developing a framework for effective audio feedback: A case study. Assessment and Evaluation in Higher Education, 39(7), 777-789. doi: $10.1080 / 02602938.2013 .870530$ 
Issa, T., Issa, T., \& Chang, V. (2012). Technology and higher education: An Australian case study. International Journal of Learning, 18(3), 223-236.

Jabbour, K. K. (2014). An analysis of the effect of mobile learning on lebanese higher education. Informatics in Education, 13(1), 1-15.

Jang, Y. (2015). Convenience matters: A qualitative study on the impact of use of social media and collaboration technologies on learning experience and performance in higher education. Education for Information, 31(1-2), 73-98. doi:10.3233/EFI-150948

Jiménez-Castillo, D., Sánchez-Fernández, R., \& Marín-Carrillo, G. M. (2017). Dream team or odd couple? Examining the combined use of lectures and podcasting in higher education. Innovations in Education and Teaching International, 54(5), 448-457. doi:10.1080/14703297.2016.1148622

Jones, N., Georghiades, P., \& Gunson, J. (2012). Student feedback via screen capture digital video: Stimulating student's modified action. Higher Education, 64(5), 593-607. doi:10.1007/s10734-0129514-7

Josefsson, P., Hrastinski, S., Pargman, D., \& Pargman, T. C. (2016). The student, the private and the professional role: Students' social media use. Education and Information Technologies, 21(6), 15831594. doi: $10.1007 / \mathrm{s} 10639-015-9403-7$

Kara, A., Cagiltay, N. E., \& Dalveren, Y. (2014). An enhanced course in digital communications. International Journal of Engineering Education, 30(4), 1048-1059.

Kingston, D. G., Eastwood, W. J., Jones, P. I., Johnson, R., Marshall, S., \& Hannah, D. M. (2012). Experiences of using mobile technologies and virtual field tours in Physical Geography: Implications for hydrology education. Hydrology and Earth System Sciences, 16(5), 1281-1286. doi:10.5194/hess-16-1281-2012

Klimova, B., \& Poulova, P. (2016). Mobile learning in higher education. Advanced Science Letters, 22(5-6), 1111-1114. doi:10.1166/asl.2016.6673

Lai, K. W., \& Hong, K. S. (2015). Technology use and learning characteristics of students in higher education: Do generational differences exist? British Journal of Educational Technology, 46(4), 725-738. doi:10.1111/bjet.12161

Lambert, N., \& Watkins, L. (2013). Meet Mohammed: Using simulation and technology to support learning. Journal of Mental Health Training, Education and Practice, 8(2), 66-75. doi:10.1108/JMHTEP-03-20120001

Lee, C. Y. (2015). The effects of online peer assessment and family entrepreneurial experience on students' business planning performance. Turkish Online Journal of Educational Technology, 14(1), 123-132.

Lemus-Zúñiga, L. G., Montañana, J. M., Buendia-García, F., Poza-Luján, J. L., Posadas-Yagüe, J. L., \& Benlloch-Dualde, J. V. (2015). Computer-assisted method based on continuous feedback to improve the academic achievements of first-year students on computer engineering. Computer Applications in Engineering Education, 23(4), 610-620. doi:10.1002/cae.21633

Lu, S. C., \& Jeng, Y. C. (2012). Mobile learning in higher education: Students' learning effectiveness. ICIC Express Letters, 6(10), 2705-2710.

Maduku, D. K. (2015). Factors of E-book Use Intentions: Perspective of Students in a Developing Country. Perspectives on Global Development and Technology, 14(6), 597-618. doi:10.1163/1569149712341364

Magogwe, J. M., Ntereke, B., \& Phetlhe, K. R. (2015). Facebook and classroom group work: A trial study involving University of Botswana Advanced Oral Presentation students. British Journal of Educational Technology, 46(6), 1312-1323. doi:10.1111/bjet.12204

Mancillas, L. K., \& Brusoe, P. W. (2016). Born Digital: Integrating Media Technology in the Political Science Classroom. Journal of Political Science Education, 12(4), 375-386. doi: $10.1080 / 15512169.2015 .1096792$

Marques, M. A., Viegas, M. C., Costa-Lobo, M. C., Fidalgo, A. V., Alves, G. R., Rocha, J. S., \& Gustavsson, I. (2014). How remote labs impact on course outcomes: Various practices using VISIR. IEEE Transactions on Education, 57(3), 151-159. doi:10.1109/TE.2013.2284156

Marstio, T., \& Kivelä, S. (2014). Technology enhanced learning in a higher education context: Building bridges by student empowerment and regional development. Nordic Journal of Digital Literacy, 2014(1), 6687. 
Mathews, S., Andrews, L., \& Luck, E. (2012). Developing a Second Life virtual field trip for university students: An action research approach. Educational Research, 54(1), 17-38. doi: $10.1080 / 00131881.2012 .658197$

Mathisen, P. (2012). Video feedback in higher education - a contribution to improving the quality of written feedback. Nordic Journal of Digital Literacy, 2012(2), 97-113.

Mattis, K. V. (2015). Flipped Classroom Versus Traditional Textbook Instruction: Assessing Accuracy and Mental Effort at Different Levels of Mathematical Complexity. Technology, Knowledge and Learning, 20(2), 231-248. doi:10.1007/s10758-014-9238-0

Menkhoff, T., \& Bengtsson, M. L. (2012). Engaging students in higher education through mobile learning: Lessons learnt in a Chinese entrepreneurship course. Educational Research for Policy and Practice, 11(3), 225-242. doi:10.1007/s10671-011-9123-8

Merhi, M. I. (2015). Factors influencing higher education students to adopt podcast: An empirical study. Computers and Education, 83, 32-43. doi:10.1016/j.compedu.2014.12.014

Migin, M. W., \& Falahat, M. (2016). Effect of social media usage on university students in an emerging country. Turkish Online Journal of Educational Technology, 2016(NovemberSpecialIssue), 803-808.

Mirriahi, N., Liaqat, D., Dawson, S., \& Gašević, D. (2016). Uncovering student learning profiles with a video annotation tool: reflective learning with and without instructional norms. Educational Technology Research and Development, 64(6), 1083-1106. doi:10.1007/s11423-016-9449-2

Muñoz-Repiso, A. G. V., \& Tejedor, F. J. T. (2012). The incorporation of ICT in higher education. the contribution of ROC curves in the graphic visualization of differences in the analysis of the variables. British Journal of Educational Technology, 43(6), 901-919. doi:10.1111/j.1467-8535.2011.01270.x

Neira, E. A. S., Salinas, J., \& Crosetti, B. B. (2017). Emerging Technologies (ETs) in education: A systematic review of the literature published between 2006 and 2016. International Journal of Emerging Technologies in Learning, 12(5), 128-149. doi:10.3991/ijet.v12i05.6939

Norman, H., Din, R., Nordin, N., \& Ryberg, T. (2013). A review on the use and perceived effects of mobile blogs on learning in higher educational settings. Asian Social Science, 10(1), 209-222. doi:10.5539/ass.v10n1p209

Novakovich, J., Miah, S., \& Shaw, S. (2017). Designing curriculum to shape professional social media skills and identity in virtual communities of practice. Computers and Education, 104, 65-90. doi:10.1016/j.compedu.2016.11.002

Olelewe, C. J., \& Agomuo, E. E. (2016). Effects of B-learning and F2F learning environments on students' achievement in QBASIC programming. Computers and Education, 103, 76-86. doi:10.1016/j.compedu.2016.09.012

Parkes, M., \& Fletcher, P. (2017). A longitudinal, quantitative study of student attitudes towards audio feedback for assessment. Assessment \& Evaluation in Higher Education, 42(7), 1046-1053. doi: $10.1080 / 02602938.2016 .1224810$

Pedró, F. (2009). New Millenium Learners in Higher Education: Evidence and Policy Implications. In International Conference on 21st Century Competencies, Brussels: OECD/CERI.

Pedro, L., Barbosa, C., \& Santos, C. (2018). A critical review of mobile learning integration in formal educational contexts. International Journal of Educational Technology in Higher Education, 15(1), 10.

Pinto, M., Souza, F., Nogueira, F., Balula, A., Pedro, L., Pombo, L., Ramos, F., Moreira, A. (2012). Tracing the use of communication technologies in higher education - a literature review. In CSEDU 2012 4th International Conference on Computer Supported Education Proceedings, Porto,181-186.

Pomerol, J. C., Epelboin, Y., \& Thoury, C. (2015). MOOCs and Higher Education. MOOCs, 83-100.

Raes, A., Vanderhoven, E., \& Schellens, T. (2015). Increasing anonymity in peer assessment by using classroom response technology within face-to-face higher education. Studies in Higher Education, 40(1), 178-193. doi:10.1080/03075079.2013.823930

Romero, M., Guitert, M., Sangrà, A., \& Bullen, M. (2013). Do UOC students fit in the net generation profile? An approach to their habits in ICT use. International Review of Research in Open and Distance Learning, $14(3), 158-181$. 
Russo, T., Zhang, J., \& Fallon, M. (2015). Influence of perceived technology use of university students on academic and social performance in college. International Journal of Interdisciplinary Civic and Political Studies, 10(2), 17-31.

Samir Abou El-Seoud, M., Taj-Eddin, I. A. T. F., Seddiek, N., El-Khouly, M. M., \& Nosseir, A. (2014). E-learning and students' motivation: A research study on the effect of e-learning on higher education. International Journal of Emerging Technologies in Learning, 9(4), 20-26. doi:10.3991/ijet.v9i4.3465

Sánchez-Lugo, J., \& Domínguez-Flores, N. (2013). The use of mobile technologies by undergraduate students from the university of Puerto Rico system. Ubiquitous Learning, 5(3), 53-66.

Sayımer, İ., Yüksel, A., \& Demir, B. (2015). Transformatıon of instructıonal and learnıng paradıgm in dıgıtal age: Socıal networkıng practıces and academıc expectatıons of higher educatıon students in Turkey. Turkish Online Journal of Educational Technology, 2015, 782-789.

Seale, J. (2013). When digital capital is not enough: Reconsidering the digital lives of disabled university students. Learning, Media and Technology, 38(3), 256-269. doi:10.1080/17439884.2012.670644

Seale, J., Georgeson, J., Mamas, C., \& Swain, J. (2015). Not the right kind of 'digital capital'? An examination of the complex relationship between disabled students, their technologies and higher education institutions. Computers and Education, 82, 118-128. doi:10.1016/j.compedu.2014.11.007

Selwyn, N. (2016). Is technology good for education? : John Wiley \& Sons.

Selwyn, N., Henderson, M., Finger, G., Larkin, K., Smart, V., and Chao, S. (2016). What works and Why? Understanding successful technology enabled learning within institutional contexts Part B Appendices. Canberra, ACT: Australian Government Office for Learning and Teaching.

Sheriff, R. E. (2012). An evaluation of students' and lecturers' use of technologies: An engineering case study. Engineering Education, 7(1), 33-46. doi:10.11120/ened.2012.07010033

Shurygin, V. Y., \& Krasnova, L. A. (2016). Electronic learning courses as a means to activate students' independent work in studying physics. International Journal of Environmental and Science Education, 11(8), 1743-1751. doi:10.12973/ijese.2016.551a

Sieche, S., Krey, B., \& Bastiaens, T. J. (2013). Investigating students' usage and acceptance of electronic books. Journal of Educational Multimedia and Hypermedia, 22(4), 465-487.

Siemens, \& Tittenberger, P. (2009). Handbook of Emerging Technologies for Learning. In. Retrieved from http://umanitoba.ca/learning_technologies/cetl/HETL.pdf

Siemens, G., \& Tittenberger, P. (2009). Handbook of Emerging Technologies for Learning. In. Retrieved from http://umanitoba.ca/learning_technologies/cetl/HETL.pdf

Singh, U. G., \& Wassermann, J. M. (2016). A Story of a Journey in Implementing an E-Assessment System at a South African University. Africa Education Review, 13(3-4), 1-16. doi: $10.1080 / 18146627.2016 .1202549$

Sleeman, J., Lang, C., \& Lemon, N. (2016). Social Media Challenges and Affordances for International Students: Bridges, Boundaries, and Hybrid Spaces. Journal of Studies in International Education, 20(5), 391-415. doi:10.1177/1028315316662975

Sobaih, A. E. E., \& Moustafa, M. A. (2016). Speaking the Same Language: The Value of Social Networking Sites for Hospitality and Tourism Higher Education in Egypt. Journal of Hospitality and Tourism Education, 28(1), 21-31. doi:10.1080/10963758.2015.1127169

Solmaz, O. (2016). \#Beyond140: Helping pre-service teachers construct a community of inquiry on twitter. Turkish Online Journal of Educational Technology, 15(4), 1-15.

Sopina, E., \& McNeill, R. (2015). Investigating the relationship between quality, format and delivery of feedback for written assignments in higher education. Assessment and Evaluation in Higher Education, 40(5), 666-680. doi:10.1080/02602938.2014.945072

Srifa, P. (2016). Learning and teaching environments by using virtual reality technology. Turkish Online Journal of Educational Technology, 2016(DecemberSpecialIssue), 1-5.

Stevenson, M. E., \& Hedberg, J. G. (2017). Mobilizing learning: a thematic review of apps in K-12 and higher education. Interactive Technology and Smart Education, 14(2), 126-137. doi:10.1108/ITSE-02-20170017 
Stewart, K. D., \& Ivala, E. (2017). Silence, voice, and "other languages": Digital storytelling as a site for resistance and restoration in a South African higher education classroom. British Journal of Educational Technology, 48(5), 1164-1175. doi:10.1111/bjet.12540

Terrion, J. L., \& Aceti, V. (2012). Perceptions of the effects of clicker technology on student learning and engagement: A study of freshmen Chemistry students. Research in Learning Technology, 20(2). doi: $10.3402 /$ rlt.v20i0.16150

Tolulope, A. E., Adenubi, O. S., \& Oluwole, F. C. (2015). Evaluating undergraduates' attitude towards the use of podcast for learning selected educational technology concepts. Global Media Journal, 2015.

Tri-Agif, I., Noorhidawati, A., \& Ghalebandi, S. G. (2016). Continuance intention of using e-book among higher education students. Malaysian Journal of Library and Information Science, 21(1), 19-33.

Umek, L., Keržič, D., Aristovnik, A., \& Tomaževič, N. (2017). An assessment of the effectiveness of moodle elearning system for undergraduate Public Administration education. International Journal of Innovation and Learning, 21(2), 165-177. doi:10.1504/IJIL.2017.081939

Valentín, A., Mateos, P. M., González-Tablas, M. M., Pérez, L., López, E., \& García, I. (2013). Motivation and learning strategies in the use of ICTs among university students. Computers and Education, 61(1), 52-58. doi:10.1016/j.compedu.2012.09.008

Vázquez-Cano, E., Meneses, E. L., \& Sánchez-Serrano, J. L. S. (2015). Analysis of social worker and educator's areas of intervention through multimedia concept maps and online discussion forums in higher education. Electronic Journal of e-Learning, 13(5), 333-346.

Viberg, O., \& Grönlund, Å. (2013). Cross-cultural analysis of users' attitudes toward the use of mobile devices in second and foreign language learning in higher education: A case from Sweden and China. Computers and Education, 69, 169-180. doi:10.1016/j.compedu.2013.07.014

Virtanen, M. A., Kääriäinen, M., Liikanen, E., \& Haavisto, E. (2017). The comparison of students' satisfaction between ubiquitous and web-basedlearning environments. Education and Information Technologies, 22(5), 2565-2581. doi:10.1007/s10639-016-9561-2

Virtanen, P., Myllärniemi, J., \& Wallander, H. (2013). Diversifying higher education: Facilitating different ways of learning. Campus-Wide Information Systems, 30(3), 201-211. doi:10.1108/10650741311330384

Waldeck, J. H., \& Dougherty, K. (2012). Collaborative communication technologies and learning in college courses: Which are used, for what purposes, and to what ends? Learning, Media and Technology, 37(4), 355-378. doi:10.1080/17439884.2011.592497

Waycott, J., Thompson, C., Sheard, J., \& Clerehan, R. (2017). A virtual panopticon in the community of practice: Students' experiences of being visible on social media. Internet and Higher Education, 35, 12-20. doi:10.1016/j.iheduc.2017.07.001

Weller, M. (2007). Virtual learning environments: Using, choosing and developing your VLE: Routledge.

Wesch, M. (2009). From Knowledgable to Knowledge-able: Learning in New Media Environments. The Academic Commons Magazine. Retrieved from http://academiccommons.org/

Wihlborg, M., Friberg, E. E., Rose, K. M., \& Eastham, L. (2017). Facilitating learning through an international virtual collaborative practice: A case study. Nurse Education Today, 61, 3-8. doi:10.1016/j.nedt.2017.10.007

Yang, J. L., Coleman, K., Das, M., \& Hawkins, N. (2015). Integrated career development learning and ePortfolios: Improving student self-efficacy in employability skills in an undergraduate science course. International Journal of Adult, Community and Professional Learning, 22(1), 1-17.

Yi, Y. J., You, S., \& Bae, B. J. (2016). The influence of smartphones on academic performance: The development of the technology-to-performance chain model. Library Hi Tech, 34(3), 480-499. doi:10.1108/LHT-04-2016-0038

Zacharis, N. Z. (2012). Predicting college students' acceptance of podcasting as a learning tool. Interactive Technology and Smart Education, 9(3), 171-183. doi:10.1108/17415651211258281

Zitzelsberger, H., Campbell, K. A., Service, D., \& Sanchez, O. (2015). Using wikis to stimulate collaborative learning in two online health sciences courses. Journal of Nursing Education, 54(6), 352-355. doi:10.3928/01484834-20150515-08 